KAROL ŁopATECKI

Uniwersytet w Białymstoku

\title{
ARTYKUEY WOJSKOWE AUTORAMENTU CUDZOZIEMSKIEGO WŁADYSŁAWA IV - OKOLICZNOŚCI POWSTANIA I ICH CHARAKTERYSTYKA
}

\section{UWAGI WSTĘPNE}

W polskiej historiografii akcentuje się reformy wojskowe Władysława IV jako jedne $\mathrm{z}$ najważniejszych przemian wojskowości staropolskiej ${ }^{1}$. Władca ten wzorując się na rozwiązaniach ze Szwecji i Europy Zachodniej, stworzył autorament cudzoziemski. W założeniu starano się odstapić od werbowania drogiego, niekarnego, a często nielojalnego żołnierza najemnego z państw ościennych. Rozwiązaniem było stworzenie oddziałów złożonych z poddanych królewskich, dowodzonych przez znających się na nowoczesnym prowadzeniu wojen oficerach - przede wszystkim cudzoziemcach i mieszkańcach Prus, Kurlandii, Inflant ${ }^{2}$. Jeszcze przed wstapieniem na tron, w 1629 r. roz-

${ }^{1}$ K. GórsKI, Historia piechoty polskiej, Kraków 1893, s. 41; J. Wimmer, Wojsko polskie w drugiej połowie XVII wieku, Warszawa 1965, s. 11,27-28; B. BARANOwSKI, Organizacja wojska polskiego $w$ latach trzydziestych $i$ czterdziestych XVII wieku, Warszawa 1957, passim.

2 Faktyczny skład narodowościowy, zob. B. BARAnowski, Skład społeczny wojska polskiego w połowie XVII wieku, «Bellona» 12 (1945), s. 807 i n.; M. NAGIELSKI, Społeczny i narodowy skład gwardii królewskiej za dwóch ostatnich Wazów (16321668), «Studia i Materiały do Historii Wojskowości» 30/1988, s. 61-102; M. KUKIEL, 
począł się werbunek do nowego typu regimentów opartych na krajowym rekrucie z zawodową, oficerską kadrą zagraniczną ${ }^{3}$ Pod koniec 1632 r. Moskwa zaatakowała WKsL. Wybrany na króla Władysław IV udał się na odsiecz twierdzy, na czele stworzonych oddziały według wzorców cudzoziemskich, co w konsekwencji doprowadziło do utworzenia tzw. autoramentu cudzoziemskiego ${ }^{4}$.

Podział wojsk na autorament narodowy i cudzoziemski stanowi oczywiście specyfikę polsko-litewską. Nie można jednakże traktować tego zjawiska jako wyjątkowego rozwiązania na tle europejskim. Tak w Rzeszy Niemieckiej, przez całe XVI stulecie, występowały odrębności pomiędzy piechotą i jazdą. Nie tylko sposób prowadzenia działań wojennych, różne podejście do tradycji rycerskich, ale przede wszystkim aspekt prawny wyróżniał te formacje. Podsumowaniem tego dualistycznego rozwoju było potwierdzenie przez sejm Rzeszy artykułów wojskowych dla wojsk pieszych w 1570 r. ${ }^{5}$ Zostały one stworzone cztery lata wcześniej przez głównego dowódcę armii ce-

Polskość i niemczyzna w cudzoziemskim autoramencie. Polskie regulaminy wojskowe z poczatku XVIII w., «Przegląd Współczesny» 36/1931, s. 204-207.

3 Taki charakter miał regiment gwardii pieszej Władysława IV, dowodzony przez Reinholda Rosena. M. Nagielski, Reinhold Rosen, [w:] Polski Stownik Biograficzny, XXXII.1, Wrocław 1989, s. 60-62; M. NAGIELSKI, Staropolska sztuka wojenna na tle przemian w zachodnioeuropejskiej wojskowości w XVII wieku, [w:] Modernizacja struktur władzy w warunkach opóźnienia. Europa Środkowa i Wschodnia na przełomie średniowiecza i czasów nowożytnych, red. M. Dygo, S. Gawlas, H. Gral, Warszawa 1999, s. 215-216.

${ }^{4}$ Podkreślić należy ocenę Szwedów, którzy oglądając popis generalny ocenili reformy Władysława IV nadzwyczaj wysoko: „równając go i z ciała i z umysłu do nieboszczyka Gustawa”. J. Radziwiłł do K. Radziwiłła, Kwidzyń 10 IX 1635, [w:] E. Koєtubaj, Życie Janusza Radziwiłła, Wilno-Witebsk 1859, s. 287.

5 Der Römischen Käyserlichen Maiestät, und des Heil. Reichs Reuter-Bestallung: Item von Bestellung des Felds, erneuert Reuter-Recht, und der Teutschen Knechten Articuln: samt Berzeichniss etlicher sonder Puncten obbemeldeter Bestallung und Artickeln anhängig, auffgerichtet auf dem Reichs-Tag zu Speyer Anno 1570, [w:] Das Teutsche Reichs-Archiv, Leipzig 1710, s. 393-412. 
sarskiej na terenie Węgier - Lazarusa von Schwendi ${ }^{6}$. Z kolei idea stworzenia w Rosji ,wojsk nowego stroju” była niemal identyczna z wzorcami polskimi. Po niezadowalających efektach wykorzystania wojsk najemnych, zdecydowano się na głęboką reformę podczas II wojny północnej. Stworzono wówczas oddziały rajtarów, dragonów i piechoty zaciągając własnych poddanych, którymi zarządzali oficerowie obcego pochodzenia. Już w latach 70. i 80. XVII stulecia oddziały te stały się podstawą militarną armii rosyjskiej, a stare formacje ostatecznie zlikwidował Piotr I Wielki?

\section{CHARAKTERYSTYKa ŹRÓDEE}

Specyfika tego typu wojsk - organizacja, dyscyplina, pragmatyka - opierała się na artykułach wojskowych. Tymczasem wiedza o tym akcie normatywnym jest nadal niewystarczająca. Stanisław Kutrzeba zwrócił uwagę, że w autoramencie cudzoziemskim obowiązywały Artykuły wojsku cudzoziemskiemu opisane w uniwersale najjaśniejszego Wtadystawa czwartego, polskiego i szwedzkiego krola ${ }^{8}$. Wydawca nie był w stanie ustalić ani miejsca ani roku ich powstania, ograniczając się jedynie do lat panowania Władysława IV (1633-1648)9. Luk

${ }^{6}$ J. W. Huntebrinker, Der Reichsartikelbrief von 1570. Zur Kodifizierung des Militärrechts in der Frühen Neuzeit, [w:] La codification perspectives transdisciplinaires, ed. G. KAMECKe, J. Le Rider, Paris 2007, s. 88-90.

${ }^{7}$ F. I. KalinyCZew, Prawowyje woprosy wojennoj organizacji russkogo gosudarstwa wtoroj połowiny XVII wieka. Gosudarstwiennoje izdatielstwo juridiczeskoj literatury, Moskwa 1954, s. 87 i n.; S. A. NIEFIEDOw, Pjerwyje szagi na puti modjernizacii Rossii: reformy sjerjediny XVII wjeka, «Woprosy Istorii» 4/2004, s. 33-52; W. W. PIENSKoJ, Popytka wojennyh reform $w$ Rossii naczala XVII wieka, «Woprosy Istorii» 11/2003, s. $127-138$.

${ }^{8}$ Polskie ustawy i artykuły wojskowe XV-XVIII wieku, wyd. S. KutrzeBA, Kraków 1937, s. XXIII-XXV, s. 209-225.

9 Ten zakres lat podje się w dalszym ciagu: U. Augustyniak, $W$ stużbie hetmana i Rzeczypospolitej. Klientela wojskowa Krzysztofa Radziwiłła (1585-1640), Warszawa 2004, s. 88; J. Polan-Haraschin, Organizacja sqdownictwa i prokuratury w wojsku polskim, Warszawa 1961, s. 35. Czasem odnotowuje się konkretny rok - 1634 (H. Wisner, Najjaśniejsza Rzeczpospolita, Warszawa 1978, s. 180; R. OstAFIŃSKI-BodLER, 
jest dużo więcej: nie wiemy jak długo regulacja ta obowiązywała, czy $\mathrm{z}$ biegiem lat była nowelizowana, czy dotyczyła też wojsk litewskich. Bardzo ważne są ustalenia Karola Koranyiego, który wykazał, że ich treść jest dosłownym tłumaczeniem szwedzkich przepisów wydanych w 1632 r. przez Gustawa Adolfa ${ }^{10}$. Tym samym ocena nowatorstwa artykułów cudzoziemskich jest bardzo niska, polegała bowiem na wyborze wzorcowych przepisów prawnych, uzupełnionych o zaledwie trzy nowe przepisy.

Podstawowym problemem przy badaniu tego aktu normatywnego jest bardzo skromna baza źródłowa. Najwcześniejszą wersję artykułów znamy z druku wydanego w 1673 r. przez Michała Kazimierza Paca $^{11}$. Następnie dwukrotnie Samuel Brodowski przedrukował tę wersję w swoich zbiorach ${ }^{12}$. W odpisach rękopiśmiennych dotychczas wskazano zaledwie na jeden XVIII-wieczny odpis pod niespotykanym tytułem Umiejętność kawaleryjska albo artykuły wojsku cudzoziemskiemu $u^{13}$. Wszystkie te wersje maja identyczne brzmienie, oparte na redakcji zaprezentowanej przez Michała Kazimierza Paca (redakcję tę w dalszej części tekstu określam jako - M).

Sady wojskowe $w$ Polskich Siłach Zbrojnych i ich kompetencje w sprawach karnych 1914-2002, Toruń 2002, s. 480).

${ }^{10} \mathrm{~K}$. KoranyI, Z badań nad polskimi i szwedzkimi artykułami wojskowymi XVII stulecia, [w:] Studia historyczne ku czci Stanisława Kutrzeby, I, Kraków 1938, s. 273282.

${ }^{11}$ Artykuly wojskowe za najaśniejszych krolow polskich i hetmanow W. Ks. L. wojsku ustanowione, a teraz, aby tym snadniej do wszytkich do wszytkich wiadomości dojść mogły i ściślej były zachowane, z rozkazania Jaśnie Wielmożnego J. Mści pana Michała Kazimierza Paca, wojewody wileńskiego, a hetmana w. W. Ks. L., do druku podane, Wilno 1673, k. $\mathrm{K}_{2}-\mathrm{M}_{2}$.

${ }_{12}$ Artykuly wojenne powaga Rzeczypospolitej, krolow polskich i hetmanow W. Ks. Litt. różnemi czasy ustanowione, [wyd. S. BRodowski], Nieśwież 1754, s. 40-92; Artykuły wojenne powaga Rzeczypospolitej, krolow polskich i hetmanow W. Ks. Litt. rożnymi czasy ustanowione, [wyd. S. Brodowski], Elblag 1755, s. 35-68.

13 Biblioteka im. Raczyńskich w Poznaniu, rkps. 67, k. 18-35. Istnieje również dokładny odpis książki hetmana Paca, przechowywany w Archiwum Państwowym w Krakowie, oddział na Wawelu, Podh. II, 154. 
Podsumowując, posługujemy się artykułami z 1673 r., które ze względu na upływ czasu, mogą mieć zmienione brzmienie. Co więcej relacje współczesnych komplikują jeszcze bardziej sytuację. Tak Samuel Brodowski, oceniał, iż wydane one zostały privata activitate ${ }^{14}$. Możliwe zreszta, iż miał w tym względzie rację, gdyż brakuje tego aktu w Metryce Koronnej ${ }^{15}$. Inny wybitny znawca wojskowości doby saskiej - Jan Kampenhauzen ${ }^{16}$. Podsumowując tę kwestię pisze: jak zaś nabożeństwo i kiedy się odprawować ma, odsytam czytelnika do artykułów wojskowych, a osobliwie na Commentarium nad Artykułami Vladislai $I V^{17}$. Jest to stwierdzenie zaskakujące. Po pierwsze zaglądając do praw wojskowych wydanych dla autoramentu cudzoziemskiego okazuje się, że brak jakichkolwiek zapisów poświęconych nabożeń$\mathrm{stwu}^{18}$. Po drugie autor podkreśla istnienie - nieznanych nauce - komentarzy do artykułów Władysława IV.

Niezwykłej wagi jest odnalezienie w Rosyjskiej Bibliotece Narodowej w Petersburgu nowej rękopiśmiennej wersji artykułów, wchodzącego w skład zbiorów gromadzonych przez Krzysztofa Radziwiłła $(\text { dalej-R })^{19}$. Dokument ten jest starannie wykonany, sporządzony jedną ręką, zawiera na końcu odręcznie narysowaną pieczęć królewską z ad-

14 W. OrganiściaK, Kodeksy wojskowe w Polsce w roku 1775, Katowice 2001, s. 52.

15 Polskie ustawy, s. 209.

${ }^{16}$ M. KuKIEL, Znakomity autor wojskowy czasów saskich - Kampenhauzen, «Przegląd Współczesny» 141/1934, 88-102.

17 J. M. J. KAMPENHAUZEN, Obserwacje do wojennych operacji i akcji, Biblioteka Kórnicka, sygn. 659, k. 10-10v.

${ }^{18}$ Króla Władysława IV artykuły wojsku cudzoziemskiemu opisane, [w:] Polskie ustawy, s. 209-224. Przy przepisywaniu artykułów Gustawa II Adolfa pominięto cały II rozdział poświęcony nabożeństwu. K. KoranYI, op. cit., s. 278; K. ŁoPATECKI, Nabożeństwa wojskowe w Rzeczypospolitej szlacheckiej: zarys organizacyjno-prawny, [w:] Rzeczypospolita państwem wielu narodowości i wyznań XVI-XVIII wiek, red. T. Ciesielski i A. FilipczaK-Kocur, Warszawa-Opole 2008, s. 524-527.

19 Российская национальная библиотека (Санкт-Петербург). Отдел рукописей, Собрание автографов П. П. Дубровского, F. 971, Авт. 321/1 (оп. 2, № 191), № 243, k. 1-10. 
notacją sigili locus ${ }^{20}$. Nowo odnaleziona kopia jest niewątpliwie odpisem z oryginału. Prezentuje poprawne brzmienie przepisów prawnych, które w redakcji Michała Kazimierza Paca nierzadko były błędnie odczytane $^{21}$. Różnica występowała również w numeracji, które w wersji M rozpoczynały się od nowa w każdym tytule, a w pierwowzorze miały kolejność zachowaną do końca. Ponadto w R, każdy tytuł posiada nazwę, przysięga odwołuje się bezpośrednio do osoby Władysława IV. Prawdziwym zaskoczeniem jest fakt, iż po wszystkich XXII tytułach rozpoczyna się Ordynacja sądów wojskowych ${ }^{22}$. Te przepisy dotyczące organizacji sądów wojskowych i procedury sądowej, znane były pod nazwą Ordynacja sqdów wojskowych za panowania krola J. Mści Jana Kazimierza postanowiona ${ }^{23}$, a co za tym idzie przyjmowało się, iż po-

${ }^{20}$ Российская национальная библиотека (Санкт-Петербург). Отдел рукописей, Собрание автографов П. П. Дубровского, F. 971, Авт. 321/1 (оп. 2, № 191), № 243, k. $13 \mathrm{v}$.

${ }^{21}$ Drobnych zmian stylistycznych jest wiele. Nierzadko jednak błędne odczytanie wyrazów przy druku z 1673 r. prowadziło do zmiany sensu artykułów, bądź utrudniało prawidłowe ich zrozumienie. Tak w świetle art. 26 (R) spóźnienie z odjazdem „kuną karany być ma”, gdy w art. VI/2 (M) zapisano „winą karany być ma”. Niezrozumiała norma zawarta w art. XI/2 (M) brzmiąca: „Ktoby też z oficerow, z żołnierzow, albo kto inszy hałasy i konfuzją w wojsku stałą nieprzyjacielowi objawił, na gardel ma być karany", nabiera sensu w art. 42 (R), które mówi nie o hałasie, lecz o haśle i przekazywaniu go wrogowi. Podobnie przepis mówiący o zastawianiu lub zahartowaniu (sic!) broni, w rzeczywistości dotyczy zastawiania i zafantowania oręża (art. $56 \mathrm{R}$ i XV/2 M). Pisząc „w kuźni nie ma ognia podkładać” w rzeczywistości powinno znajdować się sformułowanie „ku zniszczeniu nie ma ognia podkładać”. Przykładów można byłoby mnożyć.

22 Российская национальная библиотека (Санкт-Петербург). Отдел рукописей, Собрание автографов П. П. Дубровского, F. 971, Авт. 321/1 (оп. 2, № 191), № 243, k. $10 \mathrm{v} .-13 \mathrm{v}$.

${ }^{23}$ Artykuty wojskowe (...) Michata Kazimierza Paca, Wilno 1673, k. $\mathrm{K}_{2}-\mathrm{M}_{2}$; Artykuły wojenne powaga Rzeczypospolitej, krolow polskich i hetmanow W. Ks. Litt. różnemi czasy ustanowione, [wyd. S. Brodowski], Nieśwież 1754, s. 93-130; Artykuly wojenne powaga Rzeczypospolitej, krolow polskich i hetmanow W. Ks. Litt. rożnymi czasy ustanowione, [wyd. S. Brodowski], Elbląg 1755, s. 95-118; Biblioteka im. Raczyńskich w Poznaniu, 67, k. 37-48; Biblioteka PAN i PAU w Krakowie, 974, k. $159-170$. 
wstała w latach 1649-1668 24 . Tymczasem oba dokumenty wydane zostały w identycznym momencie czasowym ${ }^{25}$.

\section{CZAS I MIEJSCE OGŁOSZENIA ARTYKUŁÓW WOJSKOWYCH}

W tym miejscu doprecyzować należy czas ogłoszenia pierwotnej artykułów wojskowych dla wojska cudzoziemskiego. W świetle relacji współczesnych zostały one ogłoszone w $1633 \mathrm{r} .{ }^{26}$ Stworzono je więc na potrzeby kampanii smoleńskiej. Niestety nie znamy zarówno dokładnej daty jak i miejsca ich publikacji. Treść artykułów wskazuje na obecność króla w obozie wojskowym, oraz kontakty bojowe $\mathrm{z}$ armią przeciwnika. Świadczy o tym m.in. jedyny w pełni oryginalny przepis redakcji $\mathrm{R}$ - art. 43. Podkreślono w nim, iz nieprz[yjaci] el nasz zażywa $w$ wojsku swym błękitnej farby, tedy z wojska naszego żaden ani officier ani żotnierz nosić jej i zażywać niema tak na bindach jako i inszych wojskowych znakach ${ }^{27}$. Wynika stąd, iż podczas działań wojennych, istniały poważne trudności z odróżnieniem najemników zaciągniętych przez stronę moskiewską i polską. Stąd koniecz-

${ }^{24}$ Polskie ustawy, s. 275-282; M. PodBIERA, Wojskowy postęek sqdowy Polski przedrozbiorowej, Poznań 1925, s. 7 i n.

${ }^{25}$ Biorąc pod uwagę fakt, iż druki niemieckojęzyczne artykułów Gustawa II Adolfa zawierały część poświęconą prawu materialnemu i procesowemu, badacze przypuszczali, iż „Ordynacja sądów wojskowych” mogła być wydana już na początku panowania Władysława IV. G. BŁAszczYK, Artykuly wojskowe i ich rola dla ustroju polskich sit zbrojnych i prawa wojskowego (do końca XVII wieku), «CPH» 31.2/1979, s. 96-97.

${ }^{26}$ Napisany w połowie XVII w. anonimowy traktat pt. Dobra duchowne powinne być wolne od stanowisk $i$ stati żolnierskich datują dwa najważniejsze artykuły wojskowe (w Koronie) na lata 1609 i 1633. Svenska Riksarkivet, Skoklostersamlingen, Polska Manuskript, sygn. E 8602, k. 67.

27 Российская национальная библиотека (Санкт-Петербург). Отдел рукописей, Собрание автографов П. П. Дубровского, F. 971, Авт. 321/1 (оп. 2, № 191), № 243 , k. 5. Jest to najwcześniejsza regulacja dotycząca umundurowania wojsk polsko-litewskich w artykułach wojskowych. Por. Z. ŻYGULSKI, H. WIELECKI, Polski mundur wojskowy, Kraków 1988, s. 7-24. 
ność wyróżnienia się przy pomocy szarfy, paska lub taśmy ${ }^{28}$, w innym niż niebieskim kolorze. Dodać należy, iż wzorem dla tego przepisu mogły być artykuły Stanisława Cikowskiego z 1565 r. ${ }^{29}$

Pierwsze podjęte przez króla działania dotyczące kwestii dyscyplinarnych króla kwestiami dyscyplinarnymi w oddziałach cudzoziemskich pochodzą z kwietnia 1633 r. Wówczas Władysław wydał obersterom mandaty przypominające o zachowaniu porządku podczas werbunku i ciągnienia na miejsce koncentracji ${ }^{30}$. W drogę Władysław IV udał się z Warszawy 9 maja $1633 \mathrm{r}$. W trakcie podróży towarzyszył mu 1200-osobowy regiment piechoty Rosena i kilka choragwi jazdy. Dopiero 24 czerwca dotarł do Wilna, gdzie spędził miesiąc, spotykając się m.in. z Krzysztofem Radziwiłłem. Wychodzące wówczas uniwersały królewskie mają już dużo ostrzejszą treść - nakazuje wszystkim łapać dezerterów z piechoty, których następnie należy oddać do starostów, ci zaś bez zbędnej zwłoki mieli złapanych wieszać ${ }^{31}$. Na miejsce koncentracji pod Orszę dotarł ostatecznie 17 sierpnia. Do obozu wojskowego przygotowanego przez hetmana polnego litewskiego przybył 3 września $^{32}$. Informacje o popisie, kiedy zwyczajowo wydawano artykuły wojskowe, posiadamy z 6 września 1633 r. Wówczas odbyt król radę wojenna z obydwoma hetmanami: xięciem Radziwittem $i$ Kazanowskim. Potem przejrzat $i$ zapłacit nowe putki [rozstrzelenie - K.Ł.]. Prawdopodobieństwo ogłoszenia wówczas artyku-

28 S. B. LINDE, Słownik języka polskiego, I, Warszawa 1807, s. 108-109. O dominującej roli błękitu w barwie piechoty, zob. Z. STEFAŃSKA, Polskie ubiory wojskowe z XVI i XVII w., «Muzealnictwo Wojskowe» 2/1964, s. 301-313.

${ }^{29}$ „Cudzoziemcy, ktorzy są z nami, albo tuteczni ludzie litewscy, ktorzy są podobni ubiory Moskwie, aby znaki mieli, aby jeden w drugiego nie zawadził". Stanisława Cikowskiego wiceregenta artykuty dla wojska polskiego w W. Ks. Litewskim, [w:] Polskie ustawy, art. 13, s. 125.

30 Zob. Uniwersał Władysława IV do obersterów, Wolborz 13 IV 1633, Biblioteka Czartoryskich w Krakowie, sygn. 128, s. 249-250; Biblioteka Ossolineum we Wrocławiu, sygn. 157/II, k. 295-295v.

31 Uniwersat aby uciekajaca piechote imano, Wilno 25 VII 1633, Львівська наукова бібліотека ім. В.Стефаника, f. Ossol., rkps. 214, k. 5v.

32 D. KupIsz, Smoleńsk 1632-1634, Warszawa 2001, s. 137-140. 
łów wojskowych zwiększa się biorąc pod uwagę fakt, iż następnego dnia Władysław IV przeprowadził pierwszą akcję militarną ${ }^{33}$.

\section{Charakterystyka PRZEPisów}

Poniżej prezentuje zestawienie artykułów według redakcji R i M oraz wersji niemieckojęzycznej wydanej w Rzeszy w 1632 r. (dalej: S) ${ }^{34}$. W sytuacji, gdy przepisy różnią się w hipotezie, dyspozycji lub sankcji, odnotowuję to kursywą. Odrębności polskiej i szwedzkiej wersji wykonał Karol Koranyi, tym samym nie odnotowuje ich w niniejszej tabeli ${ }^{35}$.

\begin{tabular}{|c|c|c|}
\hline przepisy wersji R & przepisy wersji M & przepisy wersji S \\
\hline $\mathrm{I} / 1$ & $\mathrm{I} / 1$ & $\mathrm{I} / 1$ \\
\hline & & $\mathrm{I} / 2$ \\
\hline & & $\mathrm{I} / 3$ \\
\hline & & $\mathrm{I} / 4$ \\
\hline & & $\mathrm{I} / 5$ \\
\hline & & $\mathrm{I} / 6$ \\
\hline & & $\mathrm{II} / 7$ \\
\hline & & $\mathrm{II} / 8$ \\
\hline & & $\mathrm{II} / 9$ \\
\hline & & $\mathrm{II} / 10$ \\
\hline & & $\mathrm{II} / 11$ \\
\hline & & $\mathrm{II} / 2$ \\
\hline & & $\mathrm{II} / 14$ \\
\hline & & $\mathrm{III} / 15$ \\
\hline & & $\mathrm{III} / 17$ \\
\hline & & $\mathrm{II} / 18$ \\
\hline & $\mathrm{II} / 1$ & $\mathrm{IV} / 19$ \\
\hline & $\mathrm{II} / 2$ & $\mathrm{IV} / 21$ \\
\hline $\mathrm{II} / 3$ & $\mathrm{IV} / 22$ \\
\hline $\mathrm{II} / 3$ & & \\
\hline & & \\
\hline & & \\
\hline & & \\
\hline
\end{tabular}

${ }^{33}$ Relacje agenta elektora brandenburskiego Weinbeera, [w:] K. Liske, Przyczynki do historii wojny moskiewskiej z lat 1633-1634, «Biblioteka Ossolińskich»11/1868, s. 18.

${ }^{34}$ Schwedisches Kriegs-Recht oder Articuls-Brieff desz ... Herrns Gustaff Adolffs ..., Heylbrunn 1632, s. 3-35.

35 Zob. K. Koranyi, op. cit., s. 278-282. 


\begin{tabular}{|c|c|c|}
\hline przepisy wersji $\mathrm{R}$ & przepisy wersji M & przepisy wersji S \\
\hline $\mathrm{II} / 5$ & $\mathrm{II} / 4$ & IV $/ 23$ \\
\hline II/ 6 & $\mathrm{II} / 5$ & IV/24 \\
\hline $\mathrm{II} / 7$ & $\mathrm{II} / 6$ & $\mathrm{IV} / 25$ \\
\hline $\mathrm{II} / 8$ & $\mathrm{II} / 7$ & $\mathrm{IV} / 26$ \\
\hline $\mathrm{II} / 9$ & $\mathrm{II} / 8$ & IV/27 \\
\hline $\mathrm{II} / 10$ & $\mathrm{II} / 9$ & $\mathrm{IV} / 28$ \\
\hline $\mathrm{II} / 11$ & $\mathrm{II} / 10$ & IV/29 \\
\hline $\mathrm{II} / 12$ & $\mathrm{II} / 11$ & $\mathrm{IV} / 30$ \\
\hline II $/ 13$ & $\mathrm{II} / 12$ & $\mathrm{IV} / 31$ \\
\hline II/14 & II $/ 13$ & IV $/ 32$ \\
\hline III//15 & III// & $\mathrm{V} / 33$ \\
\hline III/ $/ 16$ & III $/ 2$ & $\mathrm{~V} / 34$ \\
\hline III/17 & III/ $/ 3$ & $V / 35$ \\
\hline IV/18 & IV/1 & $\mathrm{VI} / 36$ \\
\hline $\mathrm{IV} / 19$ & $\mathrm{IV} / 2$ & $\mathrm{VI} / 37$ \\
\hline $\mathrm{IV} / 20$ & $\mathrm{IV} / 3$ & $\mathrm{VI} / 38$ \\
\hline $\mathrm{IV} / 21$ & $\mathrm{IV} / 4$ & $\mathrm{VI} / 39$ \\
\hline$V / 22$ & $\mathrm{~V} / 1$ & $\mathrm{VII} / 40$ \\
\hline$V / 23$ & $V / 2$ & $\mathrm{VII} / 41$ \\
\hline V/24 & $\mathrm{V} / 3$ & $\mathrm{VII} / 42$ \\
\hline $\mathrm{V} / 25$ & $\mathrm{VI} / 1$ & $\mathrm{VII} / 43$ \\
\hline$V I / 26$ & $V I / 2$ & VIII/44 \\
\hline $\mathrm{VI} / 27$ & $\mathrm{VI} / 3$ & VIII/45 \\
\hline $\mathrm{VI} / 28$ & $\mathrm{VI} / 4$ & VIII/46 \\
\hline VII/29 & VII $/ 1$ & IX/47 \\
\hline $\mathrm{VII} / 30$ & $\mathrm{VII} / 2$ & $\mathrm{IX} / 48$ \\
\hline \multirow[t]{4}{*}{$\mathrm{VII} / 31$} & $\mathrm{VII} / 3$ & IX/49 \\
\hline & $\mathrm{VIII} / 4$ & \\
\hline & $\mathrm{VII} / 5$ & \\
\hline & $\mathrm{VII} / 6$ & \\
\hline \multirow[t]{2}{*}{$\mathrm{VII} / 32$} & $\mathrm{VII} / 7$ & $\mathrm{IX} / 50$ \\
\hline & & $\mathrm{IX} / 51$ \\
\hline VII/33 & $\mathrm{VII} / 8$ & $\mathrm{IX} / 52$ \\
\hline VIII/34 & VIII/1 & $\mathrm{X} / 53$ \\
\hline VIII/35 & $\mathrm{VIII} / 2$ & $\mathrm{X} / 54$ \\
\hline$I X / 36$ & $I X / 1$ & $\mathrm{XI} / 55$ \\
\hline IX/37 & $\mathrm{IX} / 2$ & $\mathrm{XI} / 56$ \\
\hline $\mathrm{X} / 38$ & $\mathrm{X} / 1$ & $\mathrm{XII} / 57$ \\
\hline $\mathrm{X} / 39$ & $\mathrm{X} / 2$ & XII/58 \\
\hline $\mathrm{X} / 40$ & $\mathrm{X} / 3$ & $\mathrm{XII} / 59$ \\
\hline $\mathrm{XI} / 41$ & $\mathrm{XI} / 1$ & $\mathrm{XIII} / 60$ \\
\hline$X I / 42$ & $X I / 2$ & $\mathrm{XIII} / 61$ \\
\hline \multirow{2}{*}{$\begin{array}{l}\mathrm{XI} / 42 \\
\mathrm{XI} / 43 \\
\end{array}$} & & \\
\hline & & $\mathrm{XIII} / 62$ \\
\hline
\end{tabular}




\begin{tabular}{|c|c|c|}
\hline przepisy wersji R & przepisy wersji M & przepisy wersji S \\
\hline $\mathrm{XI} / 44$ & $\mathrm{XI} / 3$ & XIII/63 \\
\hline $\mathrm{XI} / 45$ & $\mathrm{XI} / 4$ & XIII/64 \\
\hline $\mathrm{XII} / 46$ & $\mathrm{XII} / 1$ & $\mathrm{XIV} / 65$ \\
\hline $\mathrm{XII} / 47$ & $\mathrm{XII} / 2$ & $\mathrm{XIV} / 66$ \\
\hline $\mathrm{XII} / 48$ & $\mathrm{XII} / 3$ & $\mathrm{XIV} / 67$ \\
\hline $\mathrm{XII} / 49$ & $\mathrm{XII} / 4$ & $\mathrm{XIV} / 68$ \\
\hline $\mathrm{XIII} / 50$ & $\mathrm{XIII} / 1$ & $\mathrm{XV} / 69$ \\
\hline $\mathrm{XIII} / 51$ & $\mathrm{XIII} / 2$ & $\mathrm{XV} / 70$ \\
\hline $\mathrm{XIV} / 52$ & $\mathrm{XIV} / 1$ & $\mathrm{XVI} / 71$ \\
\hline $\mathrm{XIV} / 53$ & $\mathrm{XIV} / 2$ & $\mathrm{XVI} / 72$ \\
\hline XIV/54 & $\mathrm{XIV} / 3$ & $\mathrm{XVI} / 73^{36}$ \\
\hline $\mathrm{XV} / 55$ & $\mathrm{XV} / 1$ & XVII/74 \\
\hline$X V / 56$ & $X V / 2$ & XVII/75 \\
\hline $\mathrm{XV} / 57$ & $\mathrm{XV} / 3$ & XVII/76 \\
\hline $\mathrm{XVI} / 58$ & $\mathrm{XVI} / 1$ & XVIII/77 \\
\hline$X V I / 59$ & $X V I / 2$ & XVIII/78 \\
\hline $\mathrm{XVI} / 60$ & $\mathrm{XVI} / 3$ & XVIII/79 \\
\hline XVI/61 & $\mathrm{XVI} / 4$ & XVIII/80 \\
\hline $\mathrm{XVI} / 62$ & $\mathrm{XVI} / 5$ & XVIII/81 \\
\hline $\mathrm{XVI} / 63$ & $\mathrm{XVI} / 6$ & XVIII/82 \\
\hline XVII/64 & $X V I I / 1$ & $\mathrm{XIX} / 83$ \\
\hline XVII/65 & $\mathrm{XVII} / 2$ & $\mathrm{XIX} / 84$ \\
\hline XVII/66 & & $\mathrm{XIX} / 85$ \\
\hline XVII/67 & $\mathrm{XVII} / 3$ & $\mathrm{XIX} / 86$ \\
\hline XVII/68 & $\mathrm{XVII} / 4$ & $\mathrm{XIX} / 87$ \\
\hline XVII/69 & $\mathrm{XVII} / 5$ & $\mathrm{XIX} / 88$ \\
\hline XVII/70 & $\mathrm{XVII} / 6$ & XIX/89 \\
\hline XVIII/71 & XVIII/1 & $\mathrm{XX} / 90$ \\
\hline XVIII/72 & $\mathrm{XVIII} / 2$ & $\mathrm{XX} / 91$ \\
\hline XVIII/73 & XVIII/3 & $\mathrm{XX} / 92$ \\
\hline XVIII/74 & XVIII/4 & $\mathrm{XX} / 93$ \\
\hline \multirow[t]{3}{*}{ XVIII/75 } & & $\mathrm{XX} / 94$ \\
\hline & & $\mathrm{XX} / 95$ \\
\hline & & $\mathrm{XX} / 96$ \\
\hline XVIII/76 & XVIII/5 & $\mathrm{XX} / 97$ \\
\hline XIX/77 & XIX/1 & XXI/98 \\
\hline $\mathrm{XIX} / 78$ & $\mathrm{XIX} / 2$ & XXI/99 \\
\hline XIX/79 & $\mathrm{XIX} / 3$ & $\mathrm{XXI} / 100$ \\
\hline XIX/80 & XIX/4 & XXI/101 \\
\hline $\mathrm{XX} / 81$ & $\mathrm{XX} / 1$ & XXII/102 \\
\hline $\mathrm{XX} / 82$ & $\mathrm{XX} / 2$ & XXII/103 \\
\hline
\end{tabular}

${ }^{36} \mathrm{~W}$ druku artykułów szwedzkich występuje oczywista pomyłka, przepis ten numerowany jest jako 37. Schwedisches Kriegs-Recht oder Articuls-Brieff desz ... Herrns Gustaff Adolffs ..., Heylbrunn 1632, s. 23. 


\begin{tabular}{|c|c|c|}
\hline przepisy wersji $\mathrm{R}$ & przepisy wersji M & przepisy wersji S \\
\hline $\mathrm{XX} / 83$ & $\mathrm{XX} / 3$ & $\mathrm{XXII} / 104$ \\
\hline $\mathrm{XX} / 84$ & $\mathrm{XX} / 4$ & $\mathrm{XXII} / 105$ \\
\hline $\mathrm{XX} / 85$ & $\mathrm{XX} / 5$ & $\mathrm{XXII} / 106$ \\
\hline $\mathrm{XX} / 86$ & $\mathrm{XX} / 6$ & $\mathrm{XXII} / 107$ \\
\hline $\mathrm{XXI} / 87$ & $\mathrm{XX} / 7$ & $\mathrm{XXII} / 108$ \\
\hline $\mathrm{XXI} / 88$ & $\mathrm{XX} / 8$ & $\mathrm{XXIII} / 109$ \\
\hline $\mathrm{XXII} / 89$ & $\mathrm{XX} / 9$ & $\mathrm{XXIV} / 110$ \\
\hline $\mathrm{przysiega}$ & $\mathrm{przysiega}$ & $\mathrm{przysiega}$ \\
\hline $\mathrm{XXII} / 90$ & & $\mathrm{XXIV} / 111$ \\
\hline $\mathrm{XXII} / 91$ & & $\mathrm{XXIV} / 112$ \\
\hline $\mathrm{XXII} / 92]$ & & {$[\mathrm{XXIV} / 113]$} \\
\hline
\end{tabular}

Obie polskie wersje (M i R) stanowią bardzo dokładną kopię rozwiązań szwedzkich. Recepcja ta była bardziej ścisła we wcześniejszej wersji, gdzie zachowano układ tytułów oraz ciągłość numeracji przepisów. Zaledwie cztery przepisy były nieznane w armii Gustawa II Adolfa. Są to trzy normy z M (VII/4, VII/5, VII/6) oraz jedna z R (XI/43). Świadczy to, iż przez czterdzieści lat funkcjonowania drobne zmiany występowały ${ }^{37}$. Pomiędzy redakcją R i M zachodzą większe różnice. Przede wszystkim w starszej redakcji zachowały się ostatnie trzy przepisy umieszczone po przysiędze. W art. 90 zobowiązywano żołnierzy do pełnego posłuszeństwa uniwersałom i ordynansom ogłoszonych przez bęben albo trębacza. Dodatkowo w art. 91 podkreślono pełne obowiązywanie uchwalonych praw dla wszystkich ludzi zaciągających się na służbę, niezależnie od posiadanych praw i przywilejów stanowych i osobistych. Ponadto władca przyznawał sobie prawo do dowolnego zmieniania artykułów wojskowych, według własnego uznania $^{38}$. Na koniec w nienumerowanej normie nakazano odczytywać

37 Przepisy prawa karnego materialnego znalazły się również w Ordynacji sqdów wojskowych. Polskie ustawy, s. 283-291. Ich charakterystykę przeprowadził K. Koranyi, op. cit., s. 285-287.

${ }^{38}$ Był to fundamentalny przepis, charakterystyczny w procesie wzmocnienia władzy państwowej nad najemnikami. W Republice Zjednoczonych Prowincji jako pierwszy przepisy te wprowadził Wilhelm Orański dla garnizonu w Zaltbommel w 1572 r. Od tego czasu nigdy już nie określano w kontraktach i artykułach wojennych czasu służby. Nationaal Archief Den Haag, Paulus Buys, 73, karty nie paginowane; E. Swart, From „,Landsknecht” to „,Soldier”: The Low German Foot Soldiers of the 
żołnierzom pełny tekst artykułów cztery razy do roku ${ }^{39}$. Z pozostałych przepisów art. 75 groził kapitanom i podoficerom zrzucenie z urzędu, gdyby wiedzieli i zataili nieprawidłowości przy popisie, a art. 66 zakazywał pod najsurowszą karą zajmowanie się pijaństwem lub grabieżą podczas szturmu. Wszystkie te normy znane były w wersji S.

Odnalezienie redakcji $\mathrm{R}$ tylko poświadcza, iż tworząc artykuły wojskowe posługiwano się drukami szwedzkich artykułów, które wydano w tym czasie w Rzeszy ${ }^{40}$. Dodatkowo pojawiają się pierwsze zbiory praw wojskowych z komentarzem. Kluczową rolę odgrywa tu dzieło Petera Pappusa von Tratzberga Holländisch Kriegs-Recht und Artickels-Brieff. Zapoczątkowała ona typ wydawnictwa określanych jako "Corpus Iuris Militaris". Pappus w swej pracy thumaczy na niemiecki holenderskie prawa (Articulbrief ofte ordonnantie op de discipline militaire) z 1590 r., opatrując je obszernym komentarzem. Dodaje również niektóre artykuły i ekstrakty z praw niemieckich (m.in. Artickels-Brieff Maksymiliana II i Karola V). Na początku przed indeksem umieszcza grafikę Iustitia Militaris, która w obrazowy sposób przedstawia wojskowy wymiar sprawiedliwości ${ }^{41}$. Praca ta

Low Countries in the Second Half of the Sixteenth Century, "International Review of Social History» 51.1/2006, s. 82-85.

39 Российская национальная библиотека (Санкт-Петербург). Отдел рукописей, Собрание автографов П. П. Дубровского, F. 971, Авт. 321/2 (оп. 2, № 191), № 243, k. 10 .

40 Przykładowo: Schwedisches Kriegsz-Recht, Oder Artickulß-Brieff, Des ... Herrns Gvstaff Adolffs ..., Halberstadt-Kolwald 1632; Schwedisches Kriegs-Recht, oder Artikuls-Brieff deß ... Herrn Gustaff Adolffs, Mayntz 1632; Schwedisches Kriegs-Recht, oder Articuls-Brieff, deß ... Herrns Gustaff Adolffs, Meyntz-Meres 1632; Schwedisches Kriegs-Recht oder Articuls-Brieff desz ... Herrns Gustaff Adolffs ..., Heylbrunn 1632; Schwedisches Kriegs-Recht, oder Articuls-Brieff deß ... Herrn Gustaff Adolffs, Nürnberg-Endter 1632; Schwedisches Krieges-Recht, oder Articul Brieff, Sampt der General- und Obergerichts Ordnung: Wie auch des Auditors und General Gewaltigers, Rinteln 1633.

${ }^{41}$ P. Pappus von Tratzberg, Holländisch Kriegs-Recht vnd Artickels-Brieff, Frankfurt nad Menem 1632 (druk: Wolfgengam Hofmannum), ss. 12+170+11. 
stała się bardzo popularna i była wielokrotnie wydawana ${ }^{42}$. Druki te mogły one zostać przywiezione przez najemnych oficerów werbowanych za granica, ewentualne zostać zakupione przez króla lub magnatów ${ }^{43}$.

\section{ZAKRES PODMIOTOWY}

Ważnym wydaje się doprecyzowanie, kto był zobowiązany służyć wedle przewidzianych przez Władysława IV reguł. Na wstępie podkreślić należy, iż wojna 1632-1634 stanowiła akcelerator przemian prawa wojskowego. Na początku działań wojennych, w lutym $1633 \mathrm{r}$. pod Krasnem, Krzysztof Radziwiłł dla sił litewskich (jazdy i piechoty) wydał nowe artykuły wojskowe ${ }^{44}$. W czasie konfrontacji z siłami moskiewskimi wyodrębniono dla korpusu artylerii i inżynierii specjalne prawa stworzone przez Gottharda Platera. Pierwotnie obowiązywały w języku niemieckim, następnie w 1633 r. ogłoszono Artykuły panu Platerowi z strony artyleryi z niemieckiego przełożone ${ }^{45}$. Sankcję królewską otrzymały zaś Artykuły przesławnej artylerji oficierom wyższej

${ }^{42}$ Przykładowo: Holländisch Kriegs-Recht vnd Articuls-Brieff, Strasburg 1643; 'Corpus Juris Militaris': Worin das Holländisch Kriegs-Recht Vnd Articuls-Brieffen, Frankfurt nad Menem 1657; 'Corpus juris militaris', Frankfurt nad Menem 1658; Corpus juris militaris: waer in begrepen't Hollandts krijgs-recht en Articul-brief, Utrecht 1663; 'Corpus juris militaris', worinnen das holländische Krieges-Recht, und Articuls-Brieff, Frankfurt nad Menem 1665; Corpus juris militaris, waer in begrepen is 't Nederlandts krijgs-recht en articul-brief met noodige aenmerckingen ende rechtsgronden verklaert, Utrecht 1675.

43 Tak dla Janusza Radziwiłła peregrynującego wówczas po Europie Zachodniej, wysłano bestallung na zaciąg 1000 żołnierzy pieszych. Zob. J. Radziwiłł do K. Radziwiłła, Somur 26 V 1633, [w:] E. KoŁtubaj, op. cit., s. 241. Spis oddziałów zaciagniętych na kampanię smoleńską: D. KuPIsz, op. cit., s. 240-245.

44 Российская национальная библиотека, Санкт-Петербург, kol.: Avtografy Durowskogo 321.2, Nr 197, k. 1-7.

45 AGAD, Metryka Koronna, Libri legationum nr 32, k. 315v.-316v.; Biblioteka Czartoryskich w Krakowie, sygn. 128, s. 1117-1119. Jako pierwszy zwrócił na nie uwagę B. BARANowski, Organizacja wojska..., s. 149. 
i niższej rangi 6 stycznia $1634 \mathrm{r}^{46} \mathrm{~W}$ świetle diariuszy nastapiło to tego dnia, kiedy Pan Plater przybyt do obozu ze dwiema choragwiami dragonów $i$ z nimi się przed JKM monstrowa ${ }^{47}$. Dodatkowo przynajmniej oddziały rajtarii i piechoty Mikołaja Abramowicza jako uprzywilejowanemu pułkownikowi regimentu przysługiwały własne artykuły wojskowe $^{48}$. Dodać do tego należy fakt, iż wojsko kwarciane dowodzone przez Aleksandra Piaseczyńskiego oraz pozostały oddziały koronne autoramentu narodowego pod dowództwem Marcina Kazanowskiego stosowały artykuły Jana Zamoyskiego, aprobowane przez sejm w 1609 r. Podsumowując mieliśmy do czynienia z przynajmniej pięcioma systemami prawa wojskowego.

Z powyższego wynika, iż oddziały litewskie posługiwały się wówczas artykułami Krzysztofa Radziwiłła i Mikołaja Abramowicza. Korpus artylerii i inżynierii niezależnie od przynależności narodowej podporządkowany był prawu przygotowanego przez Gottharda Platera. W konsekwencji artykuły dla wojska cudzoziemskiego stosowano jedynie wobec oddziałów koronnych. Niejasna wydaje się sytuacja piechoty polskiej, która mogła używać artykułów dla wojsk kwarcianych. Z pewnością przepisom nie podlegały oddziały rajtarii, wyraźnie bowiem w artykułach cudzoziemskich podkreślono, iż obowiązują one wszystkie regimenta piesze i choragwie draganskie [rozstrzelenie - K.Ł.] ${ }^{49}$. Potwierdzają to uniwersały królewskie z tego okresu, które nakazują stosowanie jednakowych kar wobec piechoty i dragonii ${ }^{50}$. Organizacja rajtarii nadal jest tematem niezbadanym. Wydaje się, iż oprócz wojsk zaciąganych przez bęben istniały

46 Polskie ustawy, s. 225-232.

${ }^{47}$ Diariusz kampanii smoleńskiej Władystawa IV 1633-1634, oprac. M. NAGIELSKI, Warszawa 2006, s. 254.

48 Российская национальная библиотека (Санкт-Петербург). Отдел рукописей, Собрание автографов П. П. Дубровского, F. 971, Авт. 321/2 (оп. 2, № 191), № 244, k. 1-5v., 6-19, 11-15.

49 Polskie ustawy, s. 210; Российская национальная библиотека (Санкт-Петербург). Отдел рукописей, Собрание автографов П. П. Дубровского, F. 971, Авт. 321/2 (оп. 2, № 191), № 243, k. 1.

50 Львівська наукова бібліотека ім. В.Стефаника, f. Ossol., rkps. 214, k. 42 v. 
oddziały tworzone na wzór autoramentu narodowego - systemem towarzyskim $^{51}$. Sugeruje to, iż takie oddziały stosowały również tożsame z husarią i pancernymi prawa wojskowe ${ }^{52}$.

Podsumowując, artykuły były adresowane przede wszystkim do regimentu królewskiego dowodzonego przez Reinholda Rozena oraz oddziałów Henryka Denhoffa, Jakuba Weyhera, Gottharda Platera, Eliasza Arciszewskiego i Jakuba Butlera. Przede wszystkim były to oddziały formowane według wzoru cudzoziemskiego z miejscowych poddanych. Stąd konieczność wydania ich po polsku, w przeciwieństwie do najemników wojewodzica Abramowicza, które to przepisy spisano w języku niemieckim.

O świadomym działaniu naczelnego dowództwa, przekształcających oddziały najemne w autorament cudzoziemski świadczy misja dyplomatyczna przeprowadzona 8 stycznia 1634 r. przez Gottharda Platera i Samuela Przypkowskiego. Jej celem było skłócenie wojsk carskich i doprowadzenie do ich kapitulacji. W tym celu zaadresowano oddzielny list dla moskiewskich wojsk cudzoziemskich. Oczywiście podwładni Szeina odmówili przyjęcia listu skierowanego do najemników, gdyż sq w stużbie, za którq pobieraja żołd; powotywali się i na nasze przykłady. Negocjatorzy wykazali się przy negocjacjach doskonałą znajomością struktury organizacyjnej wykazując różnice wojsk cudzoziemskich w Rzeczypospolitej i Rosji. Plater thumaczył, że w innym sq u nas położeniu cudzoziemscy żotnierze, gdyż u nas podlegaja oni hetmanowi i jego rozkazów stuchaja, a u nich zaś inaczej, bo nie podlegaja Szeinowi, co wyraźnie widać na przyktadzie Lesela, który bezkarnie zabit Sandersona i nie chciat się oddać pod sąd Szeina.

${ }^{51}$ H.Ch. Holsten, Przygody wojenne 1655-1666, thum. J. LeszczyŃsKi, oprac. T. Wasilewski, red. J. Przewıocki, s. 33, 35, 44-45. Dziękuję prof. Mirosławowi Nagielskiemu za zwrócenie uwagi na to zjawisko.

${ }^{52} \mathrm{Z}$ pewnością zaś rajtaria nie stosowała się (przynajmniej do poł. XVII w.) do reguł prawa sądowego opisanego w Ordynacji sqdów wojskowych. Podczas kampanii wojskowej Janusza Radziwiłła przeciwko Kozakom, przestępstwa popełniane przez rajtarów sądzone według ogólnych zasad. Zob. AGAD, AR VI, sygn. 36, s. 528. 
Argumentacja ta została przyjęta, gdyż pismo przyjął 9 stycznia Wilhelm Roswerman ${ }^{53}$.

\section{DALSZE LOSY ARTYKUŁów WOJSKOWYCH}

Autonomiczna pozycja wojsk trybu cudzoziemskiego w WKsL istniała przez okres hetmanatu Krzysztofa Radziwiłła. Litewskie artykuły wojskowe obowiązywały w obu autoramentach, co potwierdzone zostało w artykułach z $1635 \mathrm{r}$. Nie tylko w hipotezie norm prawnych wymieniono rotmistrzów, poruczników, kapitanów, pułkowników, ale i tematyka przepisów uległa rozszerzeniu o problematykę obrony i zdobywania umocnień ${ }^{54}$. Trudna do oceny jest sytuacja dla 2 poł. XVII stulecia. Michał Kazimierz Pac wydając drukiem prawa wojskowe dla armii litewskiej umieścił tam własne artykuły wojskowe (będące przeróbką artykułów Krzysztofa Radziwiłła z 1635 r.) oraz artykuły dla wojska cudzoziemskiego i ordynację sądów wojskowych. Układ wskazuje, iż wprowadzono wówczas podział praw na autorament narodowy i cudzoziemski. Jednakże same artykuły wojskowe Michała Kazimierza Paca nadal obejmują wszystkie rodzaje wojsk, a jeden z dodanych wówczas przepisów (art. 75) dotyczył zasad formowania oddziałów dragonii ${ }^{55}$. Wydaje się jednak, iż hetman wielki litewski świadomie zaprowadził lub umocnił obowiązywanie artykułów cudzoziemskich Władysława IV dla wojsk WKsL. W Declaratio zdania o wojnie tureckiej napisanej 10 lutego 1673 r. hetman wiele miejsca poświęcił autoramentowi cudzoziemskiego. W pracy tej proponował aby miejsca oficerskie dobrym i doświadczonym dawać kawalerom, organizować jedynie większe jednostki taktyczne - regimenty, znacznie ograniczyć możliwość otrzymywania urlopów. Najważniejsze, iż upadek dyscypliny upatrywał w borgowej służbie, ale że teraz Rzpta co czwierć płacić deklaruje, nowq z pp. obersterami, dawszy im go-

53 A. S. Radziwiøt, Pamiętnik o dziejach w Polsce, I: 1632-1636, thum. i oprac. A. Przyboś, R. Żelewski, Warszawa 1980, s. 353.

\footnotetext{
${ }^{54}$ AGAD, AR II, t. 9, nr 1154, s. 1-16; Polskie ustawy, s. 232-253.

${ }^{55}$ Polskie ustawy, s. 260.
} 
towe ludzie, życzę uczynić kapitulację $e^{56}$. Zdanie to wskazuje na myśl o przywróceniu dawnego porządku wojskowego.

Poświadczeniem późniejszego zastosowania artykułów w praktyce WKsL jest jedna z trzech zachowanych wersji Ordynacji sqdów wojskowych. Na końcu właściwego aktu normatywnego znajdowały się normy prawa materialnego dla żołnierzy wraz z przysięgą składaną dla generała artylerii $\mathrm{WKsL}^{57}$. Tym samym kopię artykułów cudzoziemskich wraz z procedurą sądową posiadał litewski generał artylerii dowodzący jednocześnie regimentem cudzoziemskim.

Nadal istniała zatem niejednoznaczność w zakresie zastosowania. Możliwym rozwiązaniem było wyraźne dookreślenie w listach przypowiednich (bestallungach) - jakim prawom żołnierze podlegaja. W kancelaryjnych wzorach listów przypowiednich na zaciąg piechoty z drugiej połowy XVII stulecia podkreślano by dyscyplinę żołnierską dowódca utrzymywał podług trybu i artykułów wojska cudzoziemskiego ${ }^{58}$.

Sami żołnierze autoramentu cudzoziemskiego walczyli o utrzymanie prawnej odrębności. Niezwykle ciekawy jest opis sytuacji w polskim obozie wojskowym z 1650 r. sporządzony przez Wojciecha Miaskowskiego - sędziego podolskiego. Tego com w obozie zastał novum, inaudiium et pessimi exempli, przepomnieć nie mogę, iż się cudzoziemcy albo raczej naszyńcy po cudzoziemsku ubrani, już niemal wytamali z jurisdictiej hetmańskiej, i sqdzić się Sędziemu wojskowemu wedle artykutów wojskowych polskich nie dopuścili, $i$ po wielu alterkacyach ledwo pozwolili, aby ich Sędziowie dwaj przy jednym naszym, i to tylko w Piatek zasiadali [rozstrzelenie - K.Ł.]: tumulty wielkie robili po haśle, hałasy, race, krzyki na polskie wojsko; już w bębny byli uderzyli, na ostatek Bazar wyra-

${ }^{56}$ Materiaty do dziejów wojny polsko-tureckiej 1672-1676, wyd. J. WoLIŃSKI, «Studia i Materiały do Historii Wojskowości»10.2/1964, s. 237.

57 Polskie ustawy, s. XX, 273.

58 Vilniaus Universiteto Biblioteka, F1-813, wzorcowy list przypowiedni na regiment piechoty $\mathrm{z}$ wymieniony dowódcą - Konstantym Wiśniowieckim, karty nie paginowane. Podobna sytuacja miała miejsce dla piechoty węgierskiej: AGAD, Metryka Koronna, nr 192, k. 289v.-291. 
bowali ${ }^{59}$. Autor akcentuje upadek dyscypliny wojskowej w formacjach pieszych, co należy jednak rozpatrywać przez pryzmat antagonizmów obu autoramentów. Na marginesie tych rozważań zaakcentowany został opór formacji cudzoziemskich do stosowania prawa polskiego czyli artykułów wojskowych aprobowanych przez sejm 1609 r. Być może pod nowym królem podważano (bez rezultatu) dotychczas stosowane przepisy, próbując wprowadzić jednolite sądownictwo, wzmacniające rządy hetmanów ${ }^{60}$.

Ostatecznie dla autoramentu cudzoziemskiego zmienił artykuły wojskowe August II Mocny ${ }^{61}$. Również one stanowią niemal nieprzekształconą wersję artykułów wojskowych - tym razem saskich - ogłoszonych w zamku Ortenburg koło Budziszyna przez Jana Jerzego III z 30 XII 1680 r. $^{62}$ Analogicznie przeprowadzając dalsze reformy armii na wzór zachodnioeuropejski Piotr I ogłosił prawa wojskowe oparte na szwedzkich artykułach wojskowych Karola XI ogłoszonych w $1683 \mathrm{r}^{63}$ Tym samym na brak oryginalności artykułów dla wojska cudzoziemskiego należy patrzeć z innej perspektywy. W swoim założeniu miały być to oddziały odpowiadające wojskom zachodnim, lecz z wykorzystaniem własnych poddanych. Tym samym prawa oraz regulaminy wojskowe stanowiły instrument upodabniający armię do

59 Ojczyste spominki w pismach do dziejów dawnej Polski. Diariusze, relacji, pamiętniki itp. stużyć mogace do objaśnienia dziejów krajowych tudzież listy historyczne do panowania królów Jana Kazimierza i Michała Korybuta oraz listy Jana Sobieskiego, wyd. A. GrabowsKi, II, Kraków 1845, s. 68.

${ }^{60}$ Zob. charakterystykę autoramentu cudzoziemskiego przeprowadzoną przez feldmarszałka Fleminga, gdzie akcentowano posiadanie własnych artykułów wojskowych i regulaminów, dzięki czemu oddziały były mniej uzależnione od władzy hetmańskiej. J. H. Fleming do P. La Sarraza, 6 XI 1720, [w:] Archiwum tajne Augusta II, II, wyd. E. RACZYŃSKI, Wrocław 1843, s. 18-21.

${ }^{61}$ Różne są jednak podawane daty ich ogłoszenia: 1 XI 1697 lub 22 II 1698 r. W. OrganiściaK, Kodeksy wojskowe $w$ Polsce w roku 1775, Katowice 2001, s. 24; T. CIESIELSKI, Armia koronna w czasach Augusta III, Warszawa 2009, s. 397 i n.

${ }^{62}$ Corpus iuris militaris des heiligen Römischen Reichs, I, hrsg. J. C. LüNING, Leipzig 1723, s. 818.

${ }_{63}$ Zob. E. ANNERs, Den karolinska militärstraffrätten och Peter den stores krigsartiklar, Stockholm-Göteborg-Uppsala 1961, s. 15-80. 
wzorcowych rozwiązań. Ponadto wprowadzenie artykułów dla autoramentu cudzoziemskiego ograniczyło liczbę stosowanych systemów prawnych w armii.

\section{Podsumowanie}

Podsumowując należy stwierdzić, iż artykuły wojskowe dla autoramentu cudzoziemskiego zostały wydane prawdopodobnie 6 września 1633 r. Było to wierne tłumaczenie artykułów Gustawa II Adolfa z 1632 r., które były wówczas bardzo często wydawane drukiem ${ }^{64}$. Obowiązywały one pierwotnie w wojskach koronnych, a od 2 poł. XVII stulecia również w WKsL. Zarówno w oddziałach najemnych werbowanych za granica, jak i w wojskach rajtarii, przynajmniej w 1 poł. XVII w. nie stosowano tych artykułów. Pomimo prób marginalizacji analizowanych przepisów, przetrwały one, aż do końca panowania Jana III Sobieskiego. W tym czasie zauważalne są drobne zmiany nie tylko natury redakcyjnej, ale i dodawania oraz usuwania pojedynczych norm prawnych. Dopiero August II Mocny zdecydował się wprowadzić nowe artykuły w autoramencie cudzoziemskich opierając się na wzorcach saskich.

The Origins and Characteristics of Weadysław IV's Military Regulations for Foreign Contingents

\section{Summary}

Władysław IV's military reforms are recognized as one of the most important historical, military transformations in Poland. This ruler modeled his reforms on Swedish and Western European solutions by creating a foreign military contingent. In principle, it sought to abandon

${ }^{64}$ Podkreślić należy, iż w wojnie ze Szwecją z lat 1626-1629 wobec tworzonych oddziałów pieszych i dragońskich wprowadzano specjalne artykuły wojskowe, które jednakże nie były podstawą do tworzenia kodyfikacji z 1633 r. Zob. AGAD, Archiwum Zamoyskich, sygn. 3112, s. 289-290. 
the recruitment of expensive, undisciplined and often disloyal soldiers from neighboring countries. His solution was to create a contingent of the king's subjects led by individuals knowledgeable in the conduct of modern warfare. In 1629 , even before ascending to the throne, he began putting together a new type of regiments - one with domestic recruits led by professional foreign officers. At the end of 1632, Moscow attacked the Ground Duchy of Lithuania. Władysław IV, an elected king, went to the aid of the fortress, leading forces modeled on foreign military designs. Consequently, this led to the creation of the so-called "foreign contingent." On September $6^{\text {th }} 1633$, military regulations were announced for these new type of military forces. Those rules were a faithful translation of Gustav II Adolfs 1632 military regulations. They were originally in force in the Polish Kingdom's armies, and from the second half of the 17th century, also in the Grand Duchy of Lithuania. During the first half of the $17^{\text {th }}$ century, those regulations were not used by the contingents recruited from abroad or by reiter cavalry. Despite attempts to marginalize these regulations, they survived until the end of John III Sobieski's reign. During this period, minor editorial changes can be noted, along with the addition and removal of minor legal directives. It was not until the reign of Augustus II the Strong that new foreign contingent regulations, based on Saxon ideas, were introduced. 